\title{
Monthly Fire Behavior Patterns
}

\author{
MARK J.SCHROEDER and CRAIG C.CHANDLER
}

\begin{abstract}
From tabulated frequency distributions of fire danger indexes for a nationwide network of 89 stations, the probabilities of four types of fire behavior ranging from 'fire out' to 'critical' were calculated for each month and are shown in map form.
\end{abstract}

large fires in the West but relatively few in the East? If so, of studies conducted jointly by the Forest Service and the Weather Bureau and sponsored by the Office of Civil Defense provides some answers to your questions.

First, we had fire-weather specialists from all regions of the United States identify the weather types associated with criticalfire weather in their areas. Then we tabulated the frequency distributions of fire danger indexes for a network of 89 stations covering the 48 contiguous States. ${ }^{1}$ Fire danger data were then combined to show the level of fire danger to be expected with each weather type. ${ }^{2}$

Finally, we established four types of fire behavior based on the fire danger indexes and determined the probability of occurrence of each by type, by months, for each station. ${ }^{3}$

\footnotetext{
${ }^{1}$ Schroeder, M. J., et a1. Synoptic weather types associated with critical fire weather. Pacific SW. Forest \& Range Exp. Sta., U.S. Forest Serv., Berkeley, Calif. 492 pp. 1964. Copies of this report may be purchased from the Clearinghouse for Federal Scientific and Technical Information, U.S. Department of Commerce, Springfield, Virginia 22151.

${ }^{2} \mathrm{Hu} 11$, M. K., O'De11, C. A., and Schroeder, M. J. Critical fire weather patterns--their frequency and levels of fire danger. Pacific SW. Forest \& Range Exp. Sta., U.S. Forest Serv., Berkeley, Calif. 43 pp., illus. 1966. Copies of this report may be purchased from the Clearinghouse for Federal Scientific and Technical Information, U.S. Depart3 ment of Commerce, Springfield, Virginia 22151.

${ }^{3}$ Chandler, C. C., and Schroeder, M. J. Probability of effective post-attack fire-fighting in wildlands. U.S. Office of Civil Defense Res. Rep. 10, 9 pp. 1965. (Limited distribution.)
}

\section{OCD REVIEW NOTICE}

This report has been reviewed in the Office of Civil Defense and approved for publication. Approval does not signify that the contents necessarily reflect the views and policies of the Office of Civil Defense. Distribution of this document is unlimited.

Contract OCD-PS-65-27--Work Unit 2535A

Forest Service - U. S. Department of Agricultur 